\title{
REDAKSIONEEL
}

\section{IN DIE SKRIFLIG 1980}

Die naam van ons tydskrif saam met die jaartal spel inderdaad troos en taak vir 1980 uit. Die gebeure in Rhodesië beklemtoon dat hierdie jaar aan teoloog, predikant en Christen hoë eise gaan stel. Gaan Mugabe verklaarde Marxis wees, soos hy by die aanvang van die verkiesing verklaar het? Is hy slegs 'n Black Conscious Leader wat op rassebasis 'n reaksie teen die reste en werking van kolonialisme in Rhodesië gelei het? Is hy ten diepste 'n geïdentifiseerde Shona-nasionalis wat pragmaties Russiese wapens gebruik het en voortaan pragmaties met Westerse en Suid-Afrikaanse handel sy mense gaan opbou? Gaan die Russiese strategiese knyptang op Afrika hom dit toelaat? Die geloof in Christus sal op alle terreine die antitese met Marx gedurende 1980 baie nader die hoof moet bied. Dit is duidelik dat die Russe Mugabe sy oorwinning verseker het met die dreigement dat hy die oorlog voortsit indien hy verloor (op goeie strategiese advies?).

Rassediskriminasie bly 'n treurige erfenis uit die koloniale era. Elke keer wat ons die terme „blank, bruin, swart" besig, is ons slag. offer daarvan! As ons in 1980 verder kon wegkom van die rassistiese indeling! Dit is opmerklik hoe die Afrikaanse denke tussen rassediskriminasie en etniese identifisering verward kan raak. Dié pole gaan die Afrikaanse politieke toneel in 1980 beroer. Selfs die afgelope kongres van SARK in Hammanskraal wat hom „vroom" teen rassediskriminasie verklaar, diskrimineer op rassegrondslag en beskou „blacks" as verteenwoordigers van „,blacks". Daar is selfs „unanimously" besluit om op 'n gegewe moment die „blacks" geleentheid te gee om hulle mening ,apart" vir die kongres te gaan formuleer 'n funksie op basis van rasse-apartheid op sterkte van rassebelange en rasseklassifikasie (vgl. EPS Nr. 5, 21.2.80 p. 4).

\section{GEMEENTELIED-MELODIE}

Elders in hierdie uitgawe kom verskillende sienswyses oor die kerklied en kerkmusiek na vore. Die kerklied is in die kerklike lewe 'n gevoelige saak. Sinodale dwang oor die kerklied het op 12 Januarie 1859 tot 'n kerkbreuk in Pretoria gelei. Twee kerkregtelike beginsels het lynreg teenoor mekaar te staan gekom: die reg van die meerderheid om 'n minderheid tot sy sienswyse te dwing of die vryheid van gewete en handeling vir 'n minderheid in die kerklike t.o.v. sake wat nie op die Skrif steun nie.

\section{Melodieë geban en weer gebruik}

In die Ned. Geref. kringe gaan ook stemme teen nuwe Gesange en veranderde melodieë van Psalms op. Dit word egter vertel (ek kan dit nie beoordeel nie) dat die N.G. en N.H. Kerke melodieë wat by die Psalms uitgegooi is, in hulle Gesangbundel asiel verleen het. Gesange mag mens dus wel „lekker" sing. Psalms skynbaar nie. 
Dit is verder bekend dat dr. H. Serfontein (N.G.) en dr. J. A. Loader (N.H.) die Totius Psalmberyming afgeskryf het. Die N.G. Sinode beweeg in dié rigting. Binnekort mag die Gereformeerdes alleen met die Totius Psalmberyming in 16de eeuse musiek sit, terwyl 'n „moderne" Afrikaanse psalmberyming met eie musiek in omloop kom. Die ander twee Afrikaanse Kerke gebruik reeds nie Totiusberyminge vir die Lofsange, 10 Gebooie, Onse Vader ens. nie. Die liturgiese verskil tussen die drie Afrikaanse Kerke mag eersdaags in beryming en melodie nog vaster gelê word. Hoe gaan Gereformeerdes (jeug?) daarop reageer?

\section{Sinodegesag agter musiek}

Die Sinode van 1979 was die eerste Gereformeerde Sinode so ver ek weet wat oor musiek van 'n psalmberyming uitspraak gedoen het. Die uitspraak kan nie op Skrif of Belydenis gegrond word nie, slegs op tradisie en musiek-argumente. Met 'n klein meerderheid is sommige bekende ,lekker-sing" melodieë uit die psalmboek geban. Op talle plekke merk mens nou weerstand teen alle nuwe melodieë.

Die aandag en moeite wat musici aan die psalmmelodieë bestee het, het ons kerklike kultuurerfenis verryk. Melodieë soos byvoorbeeld dié van Ps. 145 en Skb. 24 is pragtig terwyl bv. nuwe komposisies van Ps. 119 en Ps. 147 waarskynlik ook gaan inburger. Die vraag bly egter of bepaalde melodieë van sinodeweë op musiekgronde afgedwing moet word? Waarom kan meer as een melodie nie in omloop bly en eers op grond van onbruik uit die psalmboek verwyder word nie? Die alternatief moet hom tog in kompetisie as die beter "draer" bewys en nie op „soort" om beskerming pleit nie.

Teen die melodie van bv. Ps. 18 word 'n beroep op „musiekgehalte" en karakter van die sestiende eeuse vokale lied gedoen. Psalm 18 se waarde kwalifiseer vir 'n lofspalm. Selfs gemeentes wat die nuwe melodie "geoefen" het, hef die psalm egter lusteloos, onbetrokke en alles behalwe met "lof" aan. Die ouer melodie „dra" egter die woorde. Waarom word dit dan uitgegooi? Is daar net een tipe en wel 16de eeuse kerkmusiek?

Die ideaal is seker dat 'n gemeente die gehalte van musiek moet waardeer. Wat is egter die situasie wanneer die gemeente dit klaarklyklik nie so waardeer nie? Vrae vermenigvuldig. Moet 'n Sinode (kultuur)musiek voorskryf? Is daar in die menslike geskiedenis nog net in die 16de eeu deugdelike kerkmusiek voortgebring - so veel so dat in 1976 melodieë gekomponeer moes word asof die digter nog in die 16de eeu lewe? Kom dit nie op blote repristinasie van die 16de eeu neer nie?

\section{Die melodie slegs middel}

Die 16de eeu dra sy eie kenmerke, lewenservaring en religieuse verwagting. Eksistensieel was die mense meer op die dood as die lewe ingestel. Indien ons toegee dat mense musiek vandag anders en selfs oppervlakkiger as in die 16de eeu ervaar, kan ons beweer 
dat die voorskryf van 'n „beter" melodie die „oppervlakkige” gelowige innerlik verdiep of vervreem dit die "swakker" gelowige van die gebeure in erediens? Hou die nadruk op vorm met die mens se eksistensiële situasie rekening? Sou dit nie meer logies gewees het om bewese 16de eeuse melodieë te behou en om beter alternatiewe melodië̈ (selfs uit moderne tyd) te soek wat "swakkeres" (soos bv. Ps. 18) kan uitklop nie?

Die gelowige mens sing geloof, belydenis en Woord. Die musiek is slegs middel om die inhoud te dra. Die Bybel skryf geen bepaalde musiekgenre voor nie. Dit is 'n middelmatige saak. Weliswaar het die Sinode van 1979 die gebruik van die „uitskot"-melodieë nie verbied nie. Die Sinode belet egter die druk daarvan in die psalmboek terwyl dit hoog in aanvraag is. Kom dit nie op kerklike dwang in 'n middelmatige saak van hoë gevoelswaarde neer nie?

Eenheid in die essensiële en vryheid in die middelmatige

Die stryd oor die ,ampsgewaad" op Sinodes in die vorige eeu kan hiermee vergelyk word. Gereformeerde Sinodes het hulle weerhou van uitspraak oor middelmatige sake waaroor die Skrif nie spreek nie en geweier om te reglementeer. Die vryheid van die gelowiges moes nie ingeperk word nie. Wanneer "sinodale" reglementering eenvormigheid in middelmatige liturgiese sake soos „ampsgewaad" en melodieë afdwing, hef die sinode die reg, vryheid en verantwoordelikheid van liturg en kerk op.

Die wese van die Kerk is sy eenheid in geloof, die antwoord op die Woord van God in leer en lewe. In middelmatige sake geld die Skrifbeginsel dat die een die ander uitnemender moet ag as homself. Dit geld veral t.o.v. musiek. Smaak is belangrik, maar mense verskil in gawe en instelling.

Mens kan vra, wat van die moderne jeugmusiek as kerkmusiek? 'n Mens kan hoop dat ons mense innerlik dit nooit as "kerkmusiek" sal beskou nie. Indien die drom egter al musiek is wat gelowige mense ken om Bybelse geloof te dra, is die lied op dromslag oneindig meer tot eer van die Here as geen lied nie. Moet die jong Afrikakerke ook slegs in die 16de eeuse Geneefse musiek God verheerlik?

B. S. 